ELORE (ISSN 1456-3010), vol. $13-2 / 2006$.

Julkaisija: Suomen Kansantietouden Tutkijain Seura ry. [http://cc.joensuu.fi/ loristi/2_06/mak2_06.pdf]

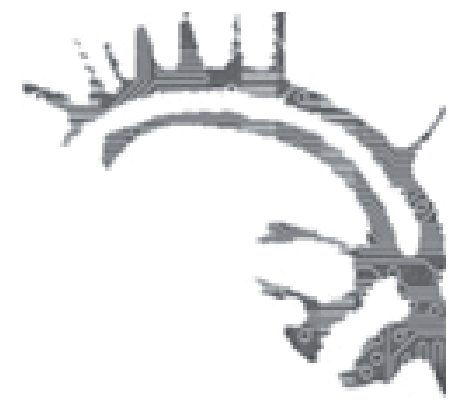

\title{
EPÄILYTTÄVÄ NAISHENKILÖ
}

\section{- MIELIKUVIA YKSINELÄJÄNAISEN SEKSUAALISUUDESTA}

\author{
Arja Mäkinen
}

Kutsun ykesineläjänaiseksi naista, joka on sekä puolisoton että lapseton. Hänen elämäntilannettaan nimitän yksineläjyydeksi. Tietoa yksineläjänaisista ei ole juurikaan koottu. Silti ihmisillä on vankkoja mielipiteitä siitä, minkälaisia henkilöitä puolisottomat ja lapsettomat naiset ovat, miten he toimivat ja kuinka heidän pitäisi muuttaa käyttäytymistään. Erityisesti yksineläjänaisten seksuaalisuus herättää runsaasti keskustelua. Yleisesti tunnetuissa stereotyyppisissä mielikuvissa yksineläjänaisen seksuaalisuus esitetään muiden naisten seksuaalisuudesta selvästi poikkeavana ja ei-hyväksyttävänä seksuaalisuutena. Kuitenkin yksineläjänaiset puhuvat itsestään seksuaalisuuttaan normaalisti ja hyväksyttävällä tavalla toteuttavina naisina. Mitä he näin tehdessään sanovat? Mihin he vetoavat? Millaisia mielikuvia he torjuvat? Miksi yksineläjänaisen seksuaalisuus mieltyy poikkeavaksi seksuaalisuudeksi?

Tarkastelen artikkelissani puolisottoman ja lapsettoman naisen seksuaalisuuteen liittyviä käsityksiä, odotuksia ja pelkoja. Samalla tutkin myös sitä, millaista naiseutta yhteiskunnassamme pidetään arvostettavana ja tavoittelemisen arvoisena (1). Käytän artikkelini aineistona yksineläjänaisten antamia haastatteluja. Lähtökohtanani ovat haastattelemieni naisten puheellaan tuottamat näkemykset omasta seksuaalisuudestaan ja asemastaan seksuaalisina toimijoina. Peilauspinnaksi haastateltujeni puheelle asetan stereotyyppiset mielikuvat, joita yksineläjänaisiin yleisesti liitetään. Kiinnitän tarkastelussani huomiota erityisesti niihin törmäyskohtiin, joissa haastateltavan kuvaus itsestään seksuaalisesti normaalina ja hyväksyttävissä olevana naisena joutuu ristiriitaan kulttuurissamme vallitsevien yksineläjänaisiin liitettyjen stereotyyppisten mielikuvien kanssa.

Aloitan artikkelin kuvailemalla tutkimukseni teoreettisia lähtökohtia ja kertomalla hankkimastani haastatteluaineistosta ja sen analysoinnista. Seuraavaksi esittelen neljä stereotyyppistä kuvausta. Jokainen neljästä kuvauksesta rakentaa oman versionsa yksineläjänaisesta ja hänen seksuaalisuuteensa kohdistuvista ennakkoluuloista. Stereotyyppisten kuvausten esittelemisen jälkeen tarkastelen yksineläjänaisen 


\section{EPÄILYTTÄVÄ NAISHENKILÖ}

seksuaalisuuteen kietoutuvia vaatimuksia. Samalla kerron myös niistä vaikeuksista, joita puolisottomat ja lapsettomat naiset kohtaavat pyrkiessään toimimaan siten, että heidän puheestaan syntyy mielikuva seksuaalisuuttaan normaalilla ja hyväksyttävällä tavalla toteuttavasta naisesta. Artikkelin viimeinen osuus toimii yhteenvetona. Lopussa esitän myös näkemykseni siitä, miksi puolisottomista ja lapsettomista naisista kertovalla tutkimustyöllä on paljon annettavanaan myös yksineläjyyttä tarkastelevan tutkimuksen ulkopuolella.

Tutkimukseni on lähtökohdiltaan naistutkimuksellisesti suuntautunutta yhteiskuntatieteellistä tutkimusta ja kertoo niistä odotuksista, joita yksineläjänaisiin liittyy. Nämä odotukset ovat kiinni omassa kulttuurisessa kontekstissaan ja saavat merkityksensä siitä kulttuurista, jossa ne syntyvät, elävät ja merkityksellistyvät yhä uudelleen. Artikkelin kirjallisena lähdeaineistona olen käyttänyt pääasiassa suomalaisia tutkimuksia, koska suomalaisen yksineläjänaisen tilanne poikkeaa monilta osin esimerkiksi Keski- tai Etelä-Euroopassa asuvan yksineläjänaisen tilanteesta. Erityisesti Tuula Gordonin (1994) ja Eija Maarit Ojalan ja Osmo Kontulan (2002) teokset ovat olleet innostajiani ja tärkeitä avainlähteitäni tiedonhankintaan.

Tutkimustyöni perustuu hermenenttiseen käsitykseen tiedonhankkimisesta. Ajattelen tiedonhankintaa kehämäisenä prosessina, jossa jo olemassa olevaa tietoa ja uusia havaintoja verrataan yhä uudelleen toisiinsa. Pidän sosiaalisesta todellisuudesta kertovaa tietoa luonteeltaan relativistisena. Tiedolla on aina kontekstinsa, josta käsin se on hankittu. Vaikka havaintojen tekijä pyrkii objektiivisuuteen, hän näkee ympäristönsä oman aikakautensa asenteiden, totena pidettyjen käsitysten ja olemassa olevien sosiaalisten rakenteiden värittämänä. Sosiaalikonstruktionistisen ajattelutavan mukaisesti miellän sosiaalisen todellisuuden tuottuvan ja uusiintuvan kielenkäytön kautta. Tarkemmin märïiteltynä tutkimukseni ankkuroituu ontologiseen konstruktionismiin. Suhtaudun sosiaaliseen todellisuuteen kielenkäytön kautta tuottuvana mutta en kokonaan kielenkäyttöön palautettavissa olevana rakenteena ja jaan näkemyksen, jonka mukaan merkitysten rakentumista on syytä tarkastella analysoitavan aineiston ulkopuolelle kurkottaen. Vuorovaikutustilanteissa tuotetut aineistot kertovat myös muusta kuin kyseisestä tilanteesta itsestään. Esimerkiksi instituutiot, vallankäyttö ja kielenkäyttäjän omaksuma käsitys itsestään sosiaalisena toimijana ovat yksittäisiä kielenkäyttötilanteita laajempia rakenteita, jotka ulottuvat paitsi vuorovaikutustilanteesta toiseen myös kielen kautta tavoitettavissa olevan todellisuuden ulkopuolelle. (Ks. Juhila 1999, 162-163, 174-176.)

Aina, kun ihmiset ovat tekemisissä keskenään, he konstruoivat itselleen, toisilleen ja kuvitteelliselle yleisölleen yhä uusia versioita omasta itsestään ja siitä ympäristöstä, jossa he elävät (Bevan \& Bevan 1999, 15-16; Jokinen ym. 1993, 17-22, 42; Potter \& Wetherell 2001, 199-200; Wetherell 2001, 16-17). Sosiaalisesta todellisuudesta annetuilla kuvauksilla on juurensa sekä meneillään olevassa vuorovaikutustilanteessa että aiemmissa tapahtumissa. Muissa tilanteissa sanottu, ajateltu ja koettu vaikuttaa siihen, millaiseksi uudet kuvaukset voivat muodostua. Keskenään vuorovaikutuksessa olevien henkilöiden omien näkemysten lisäksi myös yleisellä mielipiteellä on merkityksensä. Vallalla olevat arvot, asenteet ja käsitykset ovat yhteisesti jaettuna kulttuurisena taustatietona läsnä niissäkin tilanteissa, joissa vuorovaikutuksen osapuolet jättävät ne erikseen mainitsematta. (Edley 2001, 190; Jokinen ym. 1993, 32-33; Jokinen 


\section{ARJA MäKinen}

\& Juhila 1999, 56-57; Suoninen 1999, 26-29; Wetherell 2001, 24.) Vaikka puhuja vastustaisi yleistä mielipidettä, yleisesti totena pidetty ei pysy keskustelun ulkopuolella. Vallalla olevat näkemykset toimivat taustaoletuksina, joita vastaan tai joihin tukeutuen oman näkemyksen puolustaminen tapahtuu. Näistä lähtökohdista käsin vuorovaikutustilanteista koottu aineisto on reitti sekä tiettyyn puhetilanteeseen itseensä että sen ulkopuolella olevan yhteisesti jaetun sosiaalisen todellisuuden tarkastelemiseen.

\section{Aineistoa hanKKImassa}

\section{Haastattelemani naiset}

Haastattelin kevään ja kesän 2004 aikana kolmeakymmentäneljää suomalaista puolisotonta ja lapsetonta yksineläjänaista. (2) Haastattelupaikkakuntina toimivat Jyväskylä, Tampere ja Joensuu. Kaikki haastattelemani naiset asuivat näillä paikkakunnilla tai niiden lähistöllä. Osalla tutkimukseen osallistuneista naisista ei ollut kokemusta elämisestä avioliitossa, avoliitossa tai rekisteröidyssä parisuhteessa. Joidenkin liitto oli päättynyt eroon. Äskettäin eronneita en haastatellut. Valtaosa haastatelluista kertoi olevansa heteroseksuaalisia, mutta tutkimukseen osallistui myös ei-heteroseksuaalisiksi itsensä määritteleviä naisia.

Haastateltujen keski-iäksi muodostui 40,4 vuotta. Viittä henkilöä lukuun ottamatta kaikki haastatellut olivat 35-45-vuotiaita. Nuorin heistä oli 30-vuotias ja kaksi vanhinta olivat 47-vuotiaita. Etsin valitsemaani ikäryhmään kuuluvia haastateltavia, koska tässä yksineläjänaisen elämäntilanteen erilaisuus korostuu. Useimmat samanikäiset elävät kaikkein perhekeskeisintä elämänvaihettaan, ja heidän elämäntilanteensa jäsentyy perheen kautta (vrt. Niekka \& Petrelius 1993, 50). Osallistumisen alaikärajaksi asetin 30 vuotta. Tätä nuoremman ihmisen yksineläjyyttä ei yleensä pidetä erilaisuuden osoituksena vaan normaalina ikäkauteen liittyvänä tilanteena, jonka odotetaan lähitulevaisuudessa päättyvän perheen perustamiseen. Monet alle 30 -vuotiaat ovat vielä perheettömiä ja perustavat perheensä vasta myöhemmin. (Ojala \& Kontula 2002, 39, 126; ks. myös Sandfield \& Percy 2003, 485.) Vuosien kuluttua perheen perustamisesta yksineläjänaisten ja muiden naisten elämäntilanteet alkavat jälleen muistuttaa enemmän toisiaan (Niekka \& Petrelius 1993, 66). Vain harvoilla yli 45-vuotiailla naisilla on pieniä lapsia huollettavanaan, ja suhteellisen monet yli viisikymmenvuotiaat naiset asuvat yksin avioeron tai leskeytymisen seurauksena. Koska haluan tutkia yksineläjyyttä elämänvaiheessa, jossa sen merkitys on suurimmillaan, rajasin myös viittäkymmentä ikävuottaan lähestyvät ja sitä vanhemmat naiset tutkimukseni ulkopuolelle.

Haasteltujeni koulutustausta on heterogeeninen. Erot hankitun koulutuksen pituudessa ovat suuria. Kokonaisuutena haastattelemieni naisten koulutustaso nousee kuitenkin huomattavan korkeaksi; noin puolet haastatelluista on suorittanut yliopistotutkinnon. Yliopistokoulutettujen suuri määrä ei ollut tavoitteenani, mutta en pidä sitä myöskään yllätyksenä. Eniten koulutusta hankkineet naiset ovat muita naisia todennäköisemmin puolisottomia (Gordon 1994, 50; Ojala \& Kontula 95-100), ja pitkälle koulutetut yksineläjänaiset vaikuttavat olevan myös muita yksineläjänaisia 


\section{EPÄILYTTÄVÄ NAISHENKILÖ}

halukkaampia osallistumaan tieteellisiin tutkimuksiin (vrt. Ojala \& Kontula 2002, 24). Haastateltujeni koulutustason voi olettaa vaikuttavan aineistoni sisältöön, mutta ilman vertailuaineistoa on mahdotonta sanoa, millaisesta vaikutuksesta on kyse. Haastattelun antaneista naisista noin kolme neljäsosaa kävi töissä. Työelämän ulkopuolella olevat joko opiskelivat kokopäiväisesti, olivat työttömiä työnhakijoita tai poissa työelämästä pitkäksi muodostuneen sairausloman takia. Mikään ammattiala ei painotu aineistossani. Haastattelemieni naisten joukossa on monien eri alojen ammattilaisia.

\section{Haastattelun sisältö ja rakenne}

Laatimani haastattelu koostuu 34 kysymyksestä. Kysymysten teemoina ovat muun muassa haastateltavan arki ja hänen suhteensa aikuisuuteen, puolison asemaan, äitiyteen ja seksuaalisuuteen. Näiden teemojen lisäksi haastattelukysymykset käsittelevät naisen arvostukseen liittyviä tekijöitä, hyvinvoinnin kokemusta ja yksineläjänaisiin liittyviä stereotyyppisiä mielikuvia. Haastattelu sisältää kaksi kysymystä, jotka edellyttävät nimenomaan seksuaalisuudesta puhumista. Nämä kysymykset ovat "Mitä mieltä olet väitteestä 'aikuinen nainen tarvitsee seksiä'?" ja "Mitä haluaisit sanoa puolisottomista naisista ja seksuaalisuudesta?" Haastattelemani naiset kuitenkin puhuvat seksuaalisuudesta myös monien muiden haastattelukysymysten yhteydessä. Näin ollen käytän artikkelini aineistona koko haastatteluaineistoani enkä rajaa tarkasteluani vain tiettyjen kysymysten vastauksien analysoimiseen.

Kokonaisuutena käyttämääni haastattelua voi luonnehtia puolistrukturoiduksi teemahaastatteluksi. Haastattelu ei sisällä valmiita vastausvaihtoehtoja tarjoavia kysymyksiä. Monet kysymyksistä ovat tarkoituksellisesti yleisluontoisia, jotta niihin vastaavat voisivat tuoda esiin itselleen tärkeitä näkökulmia. Yleisluontoisten kysymysten lisäksi haastatteluun sisältyy kuitenkin myös suhteellisen tarkkarajaisia kysymyksiä ja pyyntöjä kommentoida esittämiäni väitteitä. Vastaamista rajaavat kysymykseni pitävät huolta siitä, että kaikilla tekemilläni haastatteluilla on riittävästi yhtymäkohtia toinen toisiinsa. Vähentääkseni omaa vaikutustani aineistooni pyrin laatimaan kysymykseni siten, etteivät ne preferoi mitään tiettyä vastausta eivätkä myöskään johdattele kysymyksiin vastaavia mieltämään yksineläjyyttä ennakkoluulojen värittämänä. Rakentaakseni tilaa yksineläjänaisten omille näkemyksille mainitsin yksineläjänaisiin liittyvistä stereotyyppisistä mielikuvista vasta aivan haastattelutilanteen loppuvaiheessa. Haastattelun lopussa pyysin kutakin haastattelemaani naista kommentoimaan neljää yksineläjänaisiin liittyvää stereotyppistä kuvausta. Kyseessä ovat samat kuvaukset, jotka esittelen lyhennettyinä tämän artikkelin yhteydessä. Ennen kuin haastattelemani naiset saivat kuvaukseni luettavikseen, jokainen heistä oli jo maininnut useista yksineläjänaisiin liittyvistä stereotyyppisistä käsityksistä ja ennakkoluuloista. Kuvaukset luettuaan haastateltuni totesivat tekstin kertovan asioista, joista he itse olivat vähän aiemmin puhuneet.

Ennen haastattelun aloittamista kerroin jokaiselle haastateltavalle olevani itsekin puolisoton ja lapseton yksineläjänainen. Ulkonäöstäni he pystyivät päättelemään minun olevan suunnilleen heidän ikäisensä. Uskon tiedon yksineläjyydestäni edistäneen 


\section{ARJA MäKinen}

haastelutilanteiden luontevuutta ja rakentaneen kokemusta yhteisesti jaetusta todellisuudesta. Käsitykseni mukaan yksineläjyyteni ja kuulumiseni haastateltujeni kanssa samaan ikäryhmään auttoivat minua kohdistamaan kysymyksiäni yksineläjänaisiin kohdistuviin odotuksiin ja niihin teemoihin, jotka mahdollisesti ovat tutkimukseeni osallistuville naisille merkityksellisiä. Hyvistä puolistaan huolimatta yhdistäviin tekijöihin liittyy kuitenkin myös riskinsä. Koska itsekin olen yksineläjänainen, minun on erityisen tarkasti varottava tekemästä ylitulkintaa siitä, mitä haastateltuni "itse asiassa sanoillaan tarkoittavat".

\section{Tutkimusetiikka tarkastelun kobteena}

Kaikki haastattelemani naiset osallistuivat tutkimukseen omasta halustaan ja antoivat kirjallisesti lupansa haastattelun käyttämiseen tutkimuksen lähdeaineistona. Haastatteluaineisto sisältää vain materiaalia, jonka olemassaolosta haastateltuni ovat tietoisia. Näiltä osin tutkimukseni täyttää eettiset kriteerit. Tutkimuksen etiikka on kuitenkin rehellistä aineiston hankkimista ja haastateltujen suostumusta laajempi asia. Myös haastattelukysymyksiä on syytä pohtia tutkimuseettisenä asiana. Miellän kysymysteni yleisluontoisuuden ja pyrkimykseni mahdollisimman neutraaleihin sananvalintoihin tutkimuseettisesti tärkeinä ratkaisuina. Liian yksityiskohtaiset kysymykset loukkaisivat haastateltavan yksityisyyttä, ja vahvasti tiettyä vastausvaihtoehtoa suosivat sananvalinnat kysymyksissä peittäisivät haastateltavan omat näkemykset alleen.

Tutkimusetiikkaa pohtiessani päätin, etten kategorisoi haastateltavikseni ryhtyviä heidän näkemystensä perusteella. Ihmisen luokittelu mielipiteiltään tietynlaiseksi yhden keskustelukerran jälkeen ei mielestäni ole oikeutettua. Samakin henkilö puhuu itsestään tilanteesta riippuen eri tavoin. Henkilöiden luokittelemisen sijaan etsin ja analysoin niitä puhetapoja, joilla haastateltuni kertovat itsestään ja kokemuksistaan. Jokainen haastattelemistani naisista rakentaa puheellaan useita erilaisia minäkuvia, ja toisaalta eri haastateltavat puhuvat ominaisuuksistaan ja näkemyksistään samankaltaisin sananvalinnoin. Tällä tavoin tulkittuna aineistoni avaa mahdollisuudet yksineläjänaisten kokemusten moninaisuuden tarkasteluun ilman, että minun olisi luokiteltava tutkimukseeni osallistuneet naiset entuudestaan olemassa olevien tai itse kehittelemieni yksineläjäkategorioiden jäseniksi. Vaikka eettiset näkökohdat otettaisiin huomioon, kaikilla tutkimusmetodeilla on silti rajoituksensa. Pahimpana haastattelumetodin rajoitteena pidän sitä, että haastattelutilanne suosii persoonaltaan ulospäin suuntautuvia ja henkisesti hyvin voivia henkilöitä. Yleensä vain suhteellisen hyvinvoivat ihmiset tahtovat itseään haastateltavan. Vaikeassa elämäntilanteessa olevien ihmisten näkemykset jäävät todennäköisesti haastattelemalla toteutetun tutkimuksen ulkopuolelle etenkin silloin, kuin osallistuminen perustuu haastateltavan omaan aktiivisuuteen.

Aloitin aineistoni analysoimisen etsimällä tekemistäni haastatteluista ne kohdat, joissa haastattelemani henkilö kuvailee omaa seksuaalisuuttaan positiiviseen sävyyn. Näitä kohtia löytyi jokaisesta haastatteluista. Keräsin positiivissävyistä seksuaalisuuspuhetta sisältävät tekstiosuudet yhteen ja luin täten muodostuneen tekstin 


\section{EPÄILYTTÄVÄ NAISHENKILÖ}

yhä uudelleen. Lukiessani merkitsin näkyviin ne aihepiirit, joihin positiiviset seksuaalisuuden kuvaukset aineistossani liittyvät. Artikkelini käsittelee näitä aihepiirejä. Lisäksi etsin aineistostani myös henkilökohtaisia ominaisuuksia ja luonteenpiirteitä, joita haastattelemani naiset mainitsivat positiivissävyisen seksuaalisuuspuheensa yhteydessä. Tekstin lukeminen useaan kertaan paljasti näiden ominaisuuksien olevan kiteytettävissä normaaliudesta ja hyväksyttävyydestä kertovien mielikuvien tuottamisen ympärille. Normaalius näyttäytyy aineistossani ennen kaikkea samanlaisuutena muiden naisten kanssa. Hyväksyttävyys puolestaan liittyy useimmiten seksuaalimoraalin nuhteettomaan noudattamiseen. Yksineläjänaisen seksuaalisuuden normaaliuteen ja hyväksyttävyyteen liittyvien käsitysten tarkastelu yhtäältä yksineläjänaisten omassa puheessa ja toisaalta yksineläjänaisiin liitetyissä stereotyyppisissä mielikuvissa on artikkelini keskeisintä sisältöä.

\section{STEREOTYYPPISIÄ MIELIKUVIA}

\section{Neljä stereotypiaa}

Yhteiskunnassamme vallitsee ilmeinen tarve määritellä, minkälaisia ihmisiä yksineläjänaiset ovat, miten he käyttäytyvät ja miten heidän tulisi käyttäytyä (Ojala \& Kontula 2002, 134). Mielikuvat yksineläjänaisista ovat osa aikamme arkitodellisuutta; ihmiset osaavat luetella ominaisuuksia ja luonteenpiirteitä, joita puolisottomilla ja lapsettomilla naisilla uskotaan olevan. Perehtyessäni tutkimukseni aihepiiriin ryhdyin keräämään yhteen niitä mielikuvia, joita yksineläjänaisiin kulttuurissamme liitetään. Koostin löytämistäni mielikuvista neljä stereotyyppistä yksineläjänaiskuvaa. Kussakin koostamassani kuvauksessa kiteytyy joukko yksinläjänaisiin usein yhdistettyjä käsityksiä ja ajattelumalleja.

Joissakin puolisottomuutta ja lapsettomuutta käsittelevissä tutkimuksissa on kommentoitu suomalaisiin yksineläjänaisiin liittyviä stereotyyppisiä näkemyksiä (ks. Gordon 1994, 128-132; Lehtonen 2004, 230-232; Niekka \& Petrelius 1993, 1-42, 85; Ukkonen 1999, 89-102; Vakimo 2001, 152-158), mutta koostamani naiskuvat eivät sellaisinaan perustu mihinkään tiettyyn lähdeteokseen. Tietyn lähdeteoksen sijaan kaikilla neljällä kuvauksella on juurensa sekä median tuottamien ja ylläpitämien yksineläjänaiskuvien joukossa (ks. Macdonald, 1995; Saresma 1999; Ukkonen 1999) että keskusteluissa, joita ihmisten kuulee käyvän keskenään arkisissa tilanteissa kuten esimerkiksi julkisilla kulkuneuvoilla matkustaessaan, lounastauolla ruokaillessaan tai vaikkapa ostoskeskuksen käytävillä. Vaikka laatimani kuvaukset perustuvat yleisesti tunnettuihin mielikuviin, kaikille niistä ei ole olemassa vakiintunutta nimitystä. Kutsun koostamiani yksineläjänaiskuvia nimilläperinteinen vanhapiika, city-sinkkunainen, pelästynyt reppana ja kukaties lesbo. (3)

Perinteinen vanhapiika elää selibaatissa. Hänellä ei ole seksisuhteita miesten kanssa eikä mitä todennäköisimmin tule jatkossakaan olemaan. Tämä ei ole mikään ihme, perinteisessä vanhassapiiassa on jokin ulkoinen tai sisäinen vika tai puute, joka suorastaan karkottaa miehet hänen ympäriltään. Yksikään mies ei ole kiinnostunut parisuhteesta hänen kanssaan. Perinteisen vanhanpiian elämän keskeisin tavoite on 


\section{ARJA MäKinen}

ollut ja on edelleen avioliitto. Koska tämä tavoite ei ole toteutunut, on hänestä tullut kateellinen, katkera ja kärttyisä ikäneito, jonka kanssa kaikkien on hyvin hankala tulla toimeen. Kärttyisyytensä lisäksi perinteinen vanhapiika on myös miehenkipeä: hän haluaa itselleen puolison keinolla millä hyvänsä. Yritykset löytää puoliso ovat kuitenkin tuhoon tuomittuja. Perinteinen vanhapiika pysyy puolisottomana ja lapsettomana. (Ks. Gordon 1994, 128-130; Niekka \& Petrelius 1993, 1-36; Vakimo 2001, 152-158.)

City-sinkekunainen on kunnianhimoinen, aktiivinen ja mahdollisesti myös pitkälle koulutettu. Työ, ammatti ja oman edun tavoitteleminen ovat saaneet hänen mielessään aivan liian korostuneen merkityksen. Elämänkumppanikseen city-sinkkunainen antaa ymmärtää kelpuuttavansa vain herra Täydellisyyden. Koska täydellistä miestä ei ole olemassa, city-sinkkunaiselle ei kelpaa kukaan. Tosiasiassa city-sinkkunaisen vaativuudessa ei ole kyse miehen ominaisuuksista, vaan siitä, että naista itseään riivaa täysin kyltymätön ja itsekäs vapaudenkaipuu, joka estää häntä solmimasta pysyvää parisuhdetta kenenkään kanssa. Ylipaisuneen vapaudenkaipuunsa vuoksi city-sinkkunainen välttelee avioliittoa ja kieltäytyy asettumasta aloilleen. Avioliiton solmimisen ja äidiksi ryhtymisen sijaan hän tapailee lukuisia miehiä ja viettää heidän kanssaan hyvin värikästä seksielämää tippaakaan toimintansa moraalisista seurauksista piittaamatta. (Ks. Gordon 1994, 131-132; Niekka \& Petrelius 36-42; Ukkonen 1999, 89-102; vrt. Toivanen 2001, 34-35.)

Pelästynyt reppana pitää lapsista ja ikävöi omaa perhettä ympärilleen. Kaipuustaan huolimatta pelästynyt reppana joutuu elämään yksin, koska hän ei kykene selviytymään puolison ja äidin tehtävistä normaalien naisten tavoin. Pelästyneen reppanan surullinen kohtalo johtuu siitä, että hänelle on tapahtunut jotakin todella pahaa. Tapahtuma voi olla mikä tahansa, kunhan se vain on riittävän merkittävä. Pelästynyt reppana saattaa käyttäytyä aivan kuin mitään erityistä ei olisi sattunut, mutta jotain hyvin synkkää hänen taustassaan täytyy kuitenkin olla. Muussa tapauksessa hänen kaltaisensa nainen olisi naimisissa. Osa pelästyneistä reppanoista kieltäytyy seurustelusuhteista. Osa heistä yrittää seurustella. Seurustelusuhteet kuitenkin kariutuvat kerta toisensa jälkeen, koska onnellisen perhe-elämän saavuttaminen on pelästyneelle reppanalle henkilökohtaisten traumojen vuoksi mahdotonta. (Ks. Aapola 1999, 51; vrt. Tolvanen 2001, 8; Wilkinson 1996, 12-16.)

Kukaties lesbossa ei näy mitään varsinaista vikaa. Hän on nainen, jonka luulisi jo ajat sitten löytäneen itselleen miehen ja synnyttäneen miehelleen lapsia. Jostain syystä kukaties lesbo ei kuitenkaan näytä käyttävän energiaansa Sen Oikean etsimiseen vaan on enemmän kiinnostunut muista asioista. Puhuttaessa aiemmista tai nykyisistä miessuhteista kukaties lesbo mieluiten vaikenee. Kukaties lesbo ei pukeudu naisellisuuttaan erityisesti painottaen. Korostetun naisellista käyttäytymistä hän taitaa suorastaan karttaa. Vaikuttaa siltä, ettei kukaties lesbon tuttavapiirissä ole montaakaan miestä. Selvästikin hän viettää vapaa-aikansa enimmäkseen naisten kanssa. Tarkemmin ajatellen kukaties lesbossa on paljon epäilyksiä herättävää. Kukaties lesbon kohtaaminen herättää kysymyksen siitä, kuuluuko hän lainkaan heteronaisten joukkoon. (Ks. Lehtonen 2004, 230-232; Moring 2003, 20-23; Ojala \& Kontula 2002, 85.) 


\section{EPÄILYTTÄVÄ NAISHENKILÖ}

\section{Stereotypiat ja todellisuus}

Mielikuva perinteisestä vanhastapiiasta on tuttu vanhapiikavitseistä, klassikoksi muodostuneen Meksikon pikajuna -laulun sanoista ja vanhoista suomalaisista elokuvista. Vanhapiikastereotypiaan liittyvistä käsityksistä ja uskomuksista on kirjoitettu myös tieteellisissä tutkimuksissa. Kuvaus suomalaisesta vanhapiikastereotypiasta löytyy muun muassa Tuula Gordonin (1994, 128-130), Ilse Niekan ja Päivi Petreliuksen (1993, 1-36) ja Sinikka Vakimon (2001, 152-158) teoksista. Stereotyyppinen mielikuva miehenkipeästä, seksuaalisesti epäviehättävästä ja epätoivoisesti aviopuolisoa hakevasta vanhastapiiasta oli tuttu jo agraariyhteiskunnan aikana. Vanhoistapiioista kerrottiin vitseissä, lauluissa ja varoituksensanoiksi tarkoitetuissa ohjeissa. Nuoria tyttöjä motivoitiin tekemään työnsä hyvin, ja heidän käyttäytymistään ojennettiin monin tavoin viittaamalla vanhaksipiiaksi päätymisen mahdollisuuteen. (Niekka \& Petrelius 1993, 1-36.) Agraariyhteiskuntaa ei ole enää olemassa, mutta edelleenkin ihmiset osaavat kuvailla, millaisia henkilöitä stereotyyppiset perinteiset vanhatpiiat ovat. Nykyisin vanhapiikastereotypia toimii itsereflektion lähtökohtana, mielikuvana, johon yksineläjänaiset vertaavat itseään (Ojala \& Kontula 2002, 84). Yksineläjänainen ei halua olla perinteisen vanhanpiian kaltainen, mutta saattaa pelätä, että muut näkevät hänet sellaisena (4). Vanhapiikastereotypian elinvoimaisuudesta kerrotaan aineistossani esimerkiksi näin:

[..] jos mä nïn vähä oon känkkäränke.ëtuulella ja, tuota, ei nyt asiat mee silleesti,
et en nïnku sopeudu kaikekeen munt esittää, ni varmaan joku tällä tavalla saattaa:
’No, se on taas puntteessa, että semmonen vanhapiikea". [..] Et sit mä sanon, et: "Ei
tuossa näytä liitossakaan, avioliitossakaan hyvin menevän” tai jotaki tämmöstä, että.
Mä en nïnku rupee näitä asioita selittämään, selitttelemään kenellekään. (30)

Jenni Ukkosen (1999, 89-102) artikkeli kuvaa niitä stereotyyppisiä käsityksiä, joita yksineläjänaisiin city-sinkkunaisen kaltaiseksi naisiksi miellettynä liittyy. Myös Gordonin (1994, 131-132), Ojalan ja Kontulan (2002, 43-44, 132) ja Niekan ja Petreliuksen (1993, 36-42) tutkimuksissa kerrotaan samankaltaisista mielikuvista. Tutkimuskirjallisuuden ulkopuolelta city-sinkkunaiset ovat tuttuja muun muassa suosiota saaneista fiktiivisistä televisiosarjoista, joissa nuoret ja kauniit naiset jatkavat matkaansa miesseikkailusta toiseen. City-sinkkunainen kuulostaa uudenaikaiselta, mutta myös perinteisen vanhanpiian tavoin city-sinkkunaisella on vastineensa jo sadan vuoden takaisessa historiassa.

1900-luvun alussa osalla säätyläisperheiden tyttäristä oli mahdollisuus kouluttautua opettajiksi, sairaanhoitajiksi tai muihin heille soveltuviksi katsottuihin tehtäviin. Ylempiin yhteiskuntaluokkiin kuuluvien naisten tuli kuitenkin luopua ansiotyöstään solmittuaan avioliiton. Ansiotyön tekemistä pidettiin avioliitossa olevalle säätyläisperheen tyttärelle sekä käytännössä mahdottomana että moraalisesti sopimattomana. Hyvän vaimon kuului suunnata tarmonsa miehensä ja pienten lastensa hyvinvoinnista huolehtimiseen. Monet koulutetuista naisista pysyivät naimattomina ja jatkoivat ansiotyötään vielä nuoruusvuosien jälkeenkin. Osalle heistä naimattomuus ja siihen liittyvä mahdollisuus ansiotyöhön oli tietoinen valinta. Osa eli naimattomana vastoin omaa 


\section{ARJA MäKinen}

tahtoaan. (Jallinoja 1983, 87-88; Ollila 1988, 44, 58-59, 62.) Kuvaus työlleen omistautuvasta ja avioliitosta ja äitiydestä kieltäytyvästä naisesta sopii monilta vaikkakaan ei kaikilta osin hyvin yhteen nykyajan city-sinkkunaisesta kertovan stereotypian kanssa. 1900-luvun alun mielikuvia ja käsityksiä omana aikanaan poikkeuksellista naiseutta edustaneista koulutetuista ja ansiotyötä tekevistä yksineläjänaisista voidaan pitää city-sinkkustereotypian edeltäjinä. Eräs haastatelluistani kommentoi city-sinkkustereotypiaa seuraavalla tavalla:

Yleensä mubun siis subtaudutaan sillä tavalla, et mä oon tää citysink.kunainen. [..] mä oon paljon matk.ustellu ja mulla on, tuota, ura. Eli siinä mielessä ni mua, tuota, yleensä ni kun täs aattelee mun lähipiiriä, niikeu sukulaisia ja munta, ne varmaan pitää mua enemmänki tälläsenä [city-sinkkunaisena]. [..] Ei nää kaikki asiat pidä mun osalta paikkaansa, mutta sitten on ihmisiä, joitten on pakko saada lokeroida munt. (9)

Myöskään pelästyneeksi reppanaksi nimeämäni stereotypia ei ole vailla menneisyyttä. Mielikuva raskaan elämänkohtalonsa vuoksi puolisottomaksi ja lapsettomaksi jääneestä naisesta ulottuu historian hämärään. Nykyisin käsitys, jonka mukaan erityisesti varhaislapsuuden traumaattiset kokemukset voivat heijastua vaikeuksina solmia läheisiä ihmissuhteita ja kantaa vastuuta uudesta sukupolvesta, on osa yleissivistystä. Kehityspsykologisista teorioista ja psyykkisestä hyvinvoinnista kertovista oppikirjoista on luettavissa näkemyksiä, joiden mukaan puolisosuhde ja äitiys kertovat normaalilla tavalla edenneestä henkisestä kehityksestä ja puolisottomuus ja lapsettomuus ovat osoituksia kehityksen vääristymistä tai pysähtymisestä.

Esimerkiksi useista kehityspsykologian perusoppikirjoista löytyvä Robert Havighurstin laatima kehitysvaiheteoria esittää puolisosuhteen solmimisen, vanhemmaksi tulemisen ja lasten kasvattamisen tehtävinä, joista yksilön tulee tietyssä elämänvaiheessa suoriutua siirtyäkseen kehityksessään seuraavaan vaiheeseen (Havighurst 1953, 259-262, 1. painos 1953). Myös kaikkein tunnetuimmaksi muodostuneen kehitysvaiheteorian laatija Erik Erikson liittää puolison aseman, äitiyden ja normaalisti etenevän henkisen kypsymisen toisiinsa. Eriksonin näkemyksen mukaan naisen henkisestä terveydestä kertova elämänkulku etenee parisuhteen solmimisen kautta äitiyteen ja aikuinen naiseus määrittyy kyvyksi ottaa vastaan oman puolison rakkautta ja hoivata parisuhteeseen syntyneitä lapsia. (Erikson 1983, 263-267, 283, 1. painos 1968.) Näkemys yksineläjänaisista psykososiaalisessa kehityksessään keskeneräisiksi jääneinä naisina toistuu joko suorasanaisesti ilmaistuna tai implisiittisenä taustaoletuksena myös puolisottomille naisille suunnatuissa itsehoito-oppaissa. Tyypillinen puolisottomalle naiselle suunnattu itsehoito-opas olettaa lukijansa kärsivän yksineläjyydestään ja tarvitsevan erityistä tukea kasvaakseen henkisesti siinä määrin, että parisuhteen solmiminen ja perheen perustaminen tulevat mahdollisiksi (vrt. Stroka 1985; Tolvanen 2001; Wilkinson 1995). Seuraavassa eräs haastattelemistani naisista kuvailee, miltä hänestä tuntuisi, jos häneen itseensä suhtauduttaisiin pelästyneenä reppanana.

No, oikeestaan se tuntus oikeen sä̈littävälle, että jos aateltas, että on nïn reppana, että ei oo äidiles eikä puolisoks. Et tavallaan tuntuu, et ibmiset ois saanu väärän 


\section{EPÄILYTTÄVÄ NAISHENKILÖ}

kuvan minusta. [..] Tietysti kyllä todella pahalle tuntus, jos ajateltas [..], et tosissaan jotakipitää olla pielessä, et pahasti, että et ei oo, oo päässy naimisiin. Se tietyllä tavalla tuntus tietysti aika pahalle. Et varsinki, jos ystävät, ystävät ajattelis näin. (26)

Stereotypia kukaties lesbosta vaikuttaa suurelta osin nykyajan ilmiöltä. Agraariyhteiskunta piti jäseniään homoseksuaalisina yleensä vain siinä tapauksessa, että heidän homoseksuaalisuudestaan saatiin kiisstattomia havaintoja. Esimerkiksi pelkkä yhdessä asuminen ei riittänyt homoseksuaalisuustulkinnan tekemiseen. 1900-luvun alussa kaksi naimatonta naista saattoi perustaa yhteisen kodin ilman, että heitä pidettiin naisparina. Nykyisin samaan asumisjärjestelyyn ryhtyneitä naisia todennäköisesti epäiltäisiin lesboiksi. (Löfström 1999, 73, 78, 88, 107-108, 117-118, 124.) Homoseksuaalisuus pysyi viime vuosikymmeniin saakka kulttuurisesti ja julkisesti näkymättömänä. Homoseksuaalisen käyttäytymisen miellettiin olevan harvinaista, joskin sitä voitiin pitää luonteeltaan uhkaavana ilmiönä. Tavallisen ihmisen ei oletettu olevan homoseksuaalisuuden kanssa missään tekemisissä. Kaikkein näkymättömimpiä olivat naisten väliset rakkaussuhteet. (Juvonen 2002, 158-161, 172-173, 200, 228.) Homoseksuaalisuutta hyvin harvinaisena ja poikkeavana pitävässä yhteiskunnassa ei ole tilaa käsityksille, jonka mukaan naisia voitaisiin epäillä lesboiksi pelkän puolisottomuutensa ja lapsettomuutensa perusteella.

Joissakin suomalaisista nyky-yhteiskunnasta kertovissa tutkimuksissa (ks. esim. Lehtonen 2004, 230-232; Ojala \& Kontula 2002, 85) mainitaan lyhyesti yksineläjänaisiin kohdistuvista lesboepäilyksistä. Nämä maininnat jäävät kuitenkin vain sivuhuomautuksiksi, joiden merkitystä ei tarkemmin analysoida. Kulttuurisena mielikuvana lesboksi epäiltävissä oleva nainen on helposti tavoitettavissa. Kuvaus lesboksi mieltyvästä naisesta on luettavissa esimerkiksi Anna Moringin (2003, 20-23) Tulva-lehteen kirjoittamasta artikkelista. Moring kuvailee artikkelissaan niitä odotuksia, joita lesbonaisten käyttäytymiseen ja ulkoiseen olemukseen liittyy. Karuimmillaan mielikuva yksineläjänaisesta lesboksi epäiltävissä olevana naisena löytyy niiltä internetin keskustelupalstoilta, joissa torjutuksi tulleet miehet purkavat tuntojaan. Eräs haastattelemistani naisista muistelee kokemuksiaan lesboksi epäilemisestä tällä tavalla:

[.] ykes ihminen on kysyny multa ihan suoraa, et olenko mää lesbo sen takia, että kun hän aatteli, et mä en seurustele. Ni se olis se seuraava vaibtoehto. Mut mä sanoin, mä sanoin, että en ole. [..] Sitä lesboohan mäpidin nïnku aivan käsittämättömänä. Että voidaanko, voiko tommosia asioita kysyy noin suoraan? Vaikka kysyttäs nyt vaikeka joltakin naimisissa olevalta naiselta, että: "Hei, mites sulla menee miehes kans sängyssä?" Ni en kai mä nyt keltään me semmosta kyselemään. (11)

\section{NormaAli NAINEN HALUAA SEKSIÄ JA HILlITSEE HALUNSA}

Haastateltuni puhuvat itsestään naisina, joiden seksuaalisuus on tervettä, tasapainoista ja määrältään normaalia. Useissa aineistooni sisältyvissä kommenteissa he kertovat kaipaavansa seksiä, nauttivansa siitä ja pystyvänsä seksuaalista kanssakäymistä sisäl- 


\section{ARJA MäKInen}

täviin ihmissuhteisiin. Lisäksi haastattelemani naiset voivat mainita nykyisistä tai aikaisemmista seksisuhteistaan ja siitä myönteisestä palautteesta, joita seksikumppanit ovat heistä antaneet. (5) Ensimmäisessä sitaatissa eräs haastattelemistani naisista painottaa kaikkien aikuisten ihmisten tarvitsevan seksiä. Kaksi jälkimmäistä kertoo seksistä asiana, jota puhuja itse arvostaa ja josta hän kokee saavansa nautintoa.

\section{No, kyl maar aikuinen nainen tarttee, nimenomaan aikuinen nainen tarttee seksiä. (20)}

\section{[..] kyllähän se [seksi] k.aubeen kivaakin [..] Kyllä se [seksi] nïnku kuuluu mun mielestä kuitenkin elämään, aikuisunteen (naurabdus) myös. (17)}

Sillon ku mulla oli se byvä parisubde, ni sanotaanko, että meijän subde alko siitä, että seksi oli nün byvä. (30)

Vallitsevien näkemysten mukaan seksuaalinen kanssakäyminen kuuluu normaalin aikuisen ihmisen elämään. Tyydytystä tuovaa sukupuolielämää pidetään vireyden lähteenä, ja sen katsotaan olevan todiste niin miehen kuin naisenkin henkisestä hyvinvoinnista. Vastaavasti seksisuhteen ja seksuaalisen mielenkiinnon osoitusten puuttuminen herättää epäilyksen henkilön epänormaaliudesta, sopeutumattomuudesta ja ylipäätään hänen kyvyttömyydestään solmia ja ylläpitää ihmissuhteita. (Gordon 1992, 106, 115-116, 122-127; Ojala \& Kontula 2002, 115; Ronkainen 1994a, 34; Ronkainen 1994b, 250-251.) Kuvaillessaan itseään seksuaalista kanssakäymistä kaipaavina ja siitä nauttivina naisina yksineläjänaiset rakentavat itsestään mielikuvan sekä normaaleina ihmisinä että sopivina puolisoehdokkaina, jonka rakkaussuhteet eivät kariudu seksuaalisen mielenkiinnon puuttumiseen.

Vaikka haastattelemani naiset yhtäältä puheessaan painottavat kaipaavansa seksuaalista kanssakäymistä ja nauttivansa siitä, toisaalta he korostavat kykyään hillitä halukkuuttaan ja tulla tarvittaessa toimeen ilman seksisuhteita pitkiäkin aikoja. Halua seksuaaliseen kanssakäymiseen ei kuvata niin voimakkaana, että se voisi johtaa itsekontrollin kadottamiseen. Aineistoni minäkuvaukset kertovat vahvoista yksineläjänaisista, jotka eivät sorru hyvän sukupuolimoraalin vastaisiin suhteisiin. Seksuaalisesta kanssakäymisestä kumppaninsa jo löytäneiden miesten kanssa puhutaan aineistossani hyvin paheksuvaan sävyyn. (6) Omasta itsehillinnästä ja taidosta elää tarvittaessa jopa kokonaan ilman seksisuhteita kerrotaan aineistossani esimerkiksi näillä sanoin:

[..] mulla itellä nïnku on semmonen periaate että, et jos mies on parisubteessa, ni sit minä en sitä liikuta. (24)

No, siis, ei se nyt mikään sellanen oo, et sitä [seksuaalista tyydytystä] tarvii binnalla millä hyvänsä lähtee iban mistä vaan ettimään. (7)

[..] ilman sitä [seksuaalista kanssakäymistä] oppii elämään. Sitä on pakko oppia elämään. (7) 


\section{EPÄILYTTÄVÄ NAISHENKILÖ}

Yhteiskunnassamme hyväksyttyä naiseutta tai sen puuttumista arvioidaan seksisuhteiden olemassaolon ja laadun perusteella. Seksuaalisuuttaan yhteisönsä silmin väärin tai puutteellisesti julkituova nainen ei täytä sukupuoleensa kohdistuvia vaatimuksia. (Löfström 1999, 126.) Seksuaalisen halukkuuden hillintä on tärkeä osa hyväksyttävän naiseuden tuottamista. Seksisuhde "väärän henkilön" kanssa tai "väärässä tilanteessa" toteutettuna voi johtaa "huonoksi naiseksi" leimautumiseen. (Saarikoski 1998; Saarikoski 2001.) Kertoessaan itsestään seksuaalisuutensa hillitsevinä naisina haastateltuni tuottavat mielikuvaa ihmisestä, jonka seksuaalisuus on normaalia ja hyväksyttävissä olevaa naisen seksuaalisuutta. Mielikuva "oikein" seksuaalisuuttaan toteuttavasta naisesta rakentuu aineistossani yhtäältä seksuaalisesta mielenkiinnosta kertomisen ja toisaalta seksuaalisen itsehillinnän korostamisen varaan. (7)

Pitkäkestoinen parisuhde, normaali seksuaalinen käyttäytyminen ja hyvä sukupuolimoraali liitetään kulttuurissamme yhteen (ks. Saarikoski 1998). Avo- tai avioliitossa olevat naiset voivat puheessaan rakentaa käsitystä "oikeanlaisesta" seksuaalisuudestaan asettamalla sanansa siten, että puolisosuhteen olemassaolo tulee mainituksi. Oma perhe on yleinen puheenaihe tuntemattomienkin ihmisten kesken, joten tilaisuuksia normaaliuden rakentamiseen puolisosta puhumisen kautta on runsaasti tarjolla. Yksineläjänaisten lähtökohdat seksuaalisuutensa "oikeanlaisuudesta" kertovien mielikuvien rakentamiselle ovat avo- tai aviopuolison asemassa olevien naisten lähtökohtia heikommat. Yhtäältä yksineläjänaisen seksuaalisuuteen liittyy runsaasti stereotyyppisiä, kielteisellä tavalla leimaavia mielikuvia, jotka yksineläjänaisen on pystyttävä torjumaan. Toisaalta yksineläjänainen ei voi normaaliuttaan ja hyväksyttävyyttään tuottaessaan vedota puolisosuhteen ja lasten olemassaoloon kuten perheelliset naiset tekevät.

Pitkälle aikuisikään ehtineen naisen kohdalla seurustelusuhteesta kertominen ei tuota yhtä vahvoja mielikuvia normaaliudesta kuin puolisosuhteen mainitseminen kykenisi tuottamaan. Hankalimmassa tilanteessa ovat vailla seurustelukumppania olevat yksineläjänaiset, koska he eivät voi puhua itsestään myöskään seurustelusuhteen osapuolina. Vailla seurustelukumppania oleva yksineläjänainen voi kohdata suoranaisia vaikeuksia pyrkiessään luomaan itsestään mielikuvan seksuaalisuudestaan nauttimaan kykenevänä naisena. Esimerkiksi riittävän pitkälle menevä flirttailu ja yhdenillansuhteista kertominen kylläkin vakuuttavat seksuaalisen mielenkiinnon olemassaolosta, mutta aktiivisen flirttailun ja vaihtuvista seuralaisista puhumisen seurauksena saattaa olla maineen vaarantuminen. Kuitenkin myös liian vähäisessä seksuaalisen kiinnostuksen ilmaisemisessa on sudenkuoppansa. Haastattelemani naiset kertovat yksineläjänaisiin kohdistuvien lesboepäilysten syntyvän herkästi. Jo pelkästään se, etteivät muut ihmiset havaitse yksineläjänaisen osoittavan riittävästi seksuaalista mielenkiintoa miehiä kohtaan, voi johtaa epäilykseen homoseksuaalisuudesta. Oman aineistoni lisäksi naisen yksineläjyyteen liittyvistä lesboepäilyksistä kerrotaan myös esimerkiksi Jukka Lehtosen (2004, 230-232) ja Eija Maarit Ojalan ja Osmo Kontulan (2002, 85) tutkimuksissa. (8) Seuraavissa kaksi haastattelemistani heteronaisista kertoo tapahtumista, jotka johtivat lesboepäilysten syntymiseen.

[..] byvin paljon kulen yhen mun byvän kaverin kanssa. Me käyvään iban teatterissa ja näin, niin jossakin hotellimatkalla käydään Kuopiossa tai Helsingissä teatterissa. Nin bänen korviin on kans kuul.., kantautunu sellasia, että meillä on jotain muu- 


\section{ARJA MäKinen}

takin kuin kaverisubde, että aivan varmasti. Varmana asiana on kerrottu eteenpäin.

[..] Tää on aike a yleinen mun mielestä, tällänen väite. (5)

Me yhen tytön kanssa aina liikuttiin yhessä [..]. Eri huoneessa nïnku asuttiin, mut laitettiin yhessä runat ja tällä keinon nä̈n. [..] sitten ne [samalle kurssilla opiskelevat] tytöt alkovat siinä sitten nauramaan, että hän [yksi kurssilaisista] nïnku luuli, että me ollaan niinku lesboja. (28)

\section{MITÄ YKSINELÄJÄNAISELTA ODOTETAAN?}

Aineistoni mukaan yksineläjänaisten seksuaalimoraalia epäillään jo pelkästään puolison puuttumisen perusteella. Muuta syytä epäilyksiin ei välttämättä tarvita. Epäilyksiä yksineläjänaisen sukupuolimoraalista esittävät sekä miehet että naiset. Oletus yksineläjänaisen muita naisia heikommasta seksuaalimoraalista saattaa jäädä ilmaan sanattomana vihjauksena, mutta haastateltujeni mukaan käsitystä puolisottoman ja lapsettoman yksineläjänaisen puutteellisesta seksuaalimoraalista toistetaan myös ääneen sekä yksityisissä keskusteluissa että tiedotusvälineissä julkaistavissa kannanotoissa. (9) Yksineläjänaisiin liitetyistä stereotyyppisistä mielikuvista kerrotaan aineistossani esimerkiksi näin:

[Ajatellaan, että yksineläjänainen] vamppaa kaikkien miehet. Olkaa varuillanne. [..] Pitäkää miehistänne kiinni. Että apua, nyt se vie kaikeki. Ja et se [yksineläjänainen] on just joku kaubee. (17)

[..] niìtä [yksineläjänaisia] pidetään jotenki birveen vaarallisina nïnku miesten kannalta. Et ne, ne on nïnku ilman munta niitä syöjättäriä, jotka särkee perheet ja, ja tuota rikkoo avioliitot ja vie isät lapsilta ja miehet vaimoilta [..]. (7)

Moraaliepäilysten lisäksi yksineläjiin kohdistuu myös vaatimuksia moraalinvartijuudesta. Haastateltujeni kertomusten perusteella yksineläjänaisen vastuu seksuaalimoraalista ei rajaudu vain häneen itseensä vaan se ulottuu myös kaikkiin niihin miehiin, joita hän eri tilanteissa kohtaa. Aineistossani kerrotaan odotuksista, joiden mukaan yksineläjänaisen tulee suhtautua miesten seksuaalimoraaliin epäluuloisesti ja ottaa koko moraalinen vastuu suhteen molempien osapuolten osalta kantaakseen. Yksineläjänaisen tehtävä on varmistaa, onko seksiä toivova mies hyväksyttävissä oleva kumppani, jolla ei ole parisuhdetta kenenkään toisen henkilön kanssa. Mikäli mies osoittautuu varatuksi, kunniallisen yksineläjänaisen tulee karkottaa hänet viipymättä luotaan. Aineistoni mukaan miehen ei odoteta vastaavalla tavalla ottavan selvää mahdollisen seksikumppaninsa elämäntilanteesta eikä myöskään käskevän naista poistumaan, mikäli nainen osoittautuu jonkun toisen henkilön puolisoksi tai seurustelukumppaniksi. (10)

Haastattelemani naiset eivät kommenteissaan kyseenalaista naisen vastuuta omasta käyttäytymisestään. Jotkut aineistoni puheenvuorot kuitenkin vastustavat yksineläjänaisen sijoittamista kaksinkertaiseen vastuuseen, jolloin hänen on vastattava 


\section{EPÄILYTTÄVÄ NAISHENKILÖ}

oman käytöksensä lisäksi myös miesten käyttäytymisestä. (11) Seuraavissa sitaateissa kerrotaan näkemyksistä, joiden mukaan yksineläjänaiset ovat vastuussa siitä, pettävätkö parisuhteessa olevat miehet vaimoaan tai naisystäväänsä. Jos mies on uskoton, vika on yksinomaan yksineläjänaisessa, joka ei ole kantanut omaa vastuutaan.

Kun alkaa kevät tulemaa, aurinko paistamaan, nïn sitä taas sinkekunaiset saavat kaikeki syyt niskoilleen; että, että jok.u mies on jotakuta naista pettäny [..]. (28)

[Lehden yleisöosastolla oli] tämmöstä kirjoittelua nimenomaan, että miten niinku sinkeknnaiset tulee ja nappaavat viattomat miehet. Et missään vaiheessa [lehtikirjoituksissa] ei ollu sitä, et mik.ä on miehen rooli. Et jäi siinä ihan semmonen olo, et se mies on sïnä semmonen nïnku tahdoton, surkee ja avuton. Et vaimo kiskoo toisesta päästä ja sitte toisesta päästä kiskoo nämä kamalat sinkk.knaiset [..]. Et niinku miehellä oo niinku mittää aivoja. Miehellä ei oo mittää tabtoa eikeä munta. (29)

Miesten seksuaalisuuden hillitsemistä on pidetty ja osin pidetään yhä sekä naisen velvollisuutena että naissukupuoleen liittyvänä luonnollisena ominaisuutena, osana "naisen luontoa" (Jokinen 2005, 146-147; Räisänen 1995, 156-157; Saarikoski 2001, 29). Koska yksineläjänaiset ovat naisia, odotus kyvystä kontrolloida miehen seksuaalisuutta koskee naisina myös heitä. Yhtäl̈lä yksineläjänaiselta odotetaan miehen moraalin vartioimista, mutta toisaalta hänen epäillään olevan kyvytön toimimaan tämän odotuksen mukaisesti. Yksineläjänaisten uskotaan olevan muita naisia kiinnostuneempia miesseuran etsimisestä, koska heillä ei ole omaa puolisoa. Lisäksi jo naisen yksineläjyyteen sinänsä liittyy epäilys heikosta sukupuolimoraalista. (Gordon 1994, 106, 116, 126; Saarikoski 1998,178; Ukkonen 1999, 89-102). Koska odotukset ja mielikuvat ovat keskenään näin ristiriitaisia, yksineläjänainen on vaikean tehtävän edessä yrittäessään tuottaa itsestään mielikuvaa seksuaalisuuttaan hyväksyttävästi ilmaisevana naisena.

Normatiiviseen naiseuteen sisältyy oman seksuaalisuuden ja miehen seksuaalisuuden hillitsemisvaatimusten lisäksi myös käsitys siitä, millaista seksiä naisen tulee pitää tavoiteltavana ja nautittavana. Useimmissa tapauksissa hyväksyttävä naiseus nähdään seurustelueetoksen mukaisena käyttäytymisenä. Seurustelueetos on suhtautumistapa, joka tuomitsee rakkaudettoman seksin tyhjänä, arvottomana ja todellista mielihyvää tuottamattomana. Seurustelueetoksen mukaan seksisuhteeseen tulee ryhtyä vain siinä tapauksessa, että suhteen molemmat osapuolet rakastavat toisiaan. Tämän edellytyksen seurustelueetos tulkitsee täyttyvän tilanteessa, jossa seksisuhteen osapuolet ovat seurustelu- tai puolisosuhteessa keskenään. (Saarikoski 2001, 187-189, 192.) Vaikka vailla seurustelukumppania oleva yksineläjänainen etsisi seksikumppaneikseen vain ilman parisuhdetta olevien miehiä, hänen käyttäytymistään voitaisiin silti paheksua. Seurustelueetoksen mukaan vailla seurustelukumppania olevilla naisilla ei tulisi olla lainkaan seksisuhteita ennen kuin he löytävät pitkäaikaisen kumppanin omaksi rakkaakseen. 


\section{ARJA MäKinen}

\section{YKSINELÄJÄNAISEN SEKSUAALISUUS ON EPÄILYTTÄVÄÄ}

Työpaikkojen käytäväkeskusteluissa kuiskaillaan puolisottomaan ja lapsettomaan naiseen kohdistuvista homoseksuaalisuusepäilystä. Kirjakauppojen hyllyiltä löytyy itsehoito-oppaita, jotka neuvovat yksineläjänaista kohti seksuaalista ja henkistä eheytymistä. Nettipalstoilla nauretaan miehenpuutteessa elävistä vanhoistapiioista kertoville vitseille. Televisio viihdyttää katsojiaan kuvitteellisten sinkkunaisten värikkäästä seksielämästä kertovilla sarjaohjelmilla. Kiistatta kulttuurimme kykenee tuottamaan puhetta yksineläjänaisen seksuaalisuudesta. Runsaudestaan ja monipuolisuudestaan huolimatta yksineläjänaista määrittelevä puhe on kuitenkin hätkähdyttävän värittynyttä; se ei kerro heteroseksuaalisuuttaan hyväksyttävällä tavalla toteuttavasta naisesta eikä pysähdy huomioimaan yksineläjänaisen omia kokemuksia.

Yksineläjänaisten määritteleminen heidän oman kokemuksensa ulkopuolelta näkyy sanaston puuttumisena. Kielessämme ei ole yleisesti käytössä olevaa sävyltään neutraalia puolisotonta ja lapsetonta naista tarkoittavaa sanaa. (12) Yksineläjänaisista puhutaan sinkkuina tai perinteisemmin vanhoinapiikoina, mutta osa puolisottomista ja lapsettomista naisista kokee kummankin näistä sanoista loukkaavana; sekä sinkku että vanhapiika värittävät kohteensa henkilöksi, jolla oletetaan olevan tietynlainen luonne ja elämänhistoria. Sanojen puuttuminen kiinnittää huomiota, mutta kyse ei ole pelkästään sanoista. Sanojen lisäksi puuttumaan jäävät myös yleisesti tunnetut yksineläjyyden normaaliksi ja neutraaliksi asiaksi määrittelevät mielikuvat.

Erityisen selvästi mielikuvien värittyneisyys tulee ilmi yksineläjänaisen seksuaalisuuteen liittyvissä käsityksissä. Stereotypiat vailla seksuaalista viehätysvoimaa olevasta perinteisestä vanhastapiiasta, moraalittomiin seksiseikkailuihin sortuvasta citysink.kunaisesta, traumaattisten kokemustensa seurauksena parisuhteeseen kyvyttömäksi tulleesta pelästyneestä reppanasta ja homoseksuaalisuuttaan piilottelevasta kukaties lesbosta eivät kerro seksuaalisuuttaan normatiivisten odotusten mukaisesti toteuttavasta naisesta. Kaikki neljä yksineläjänaiskuvaa kylläkin tuovat esiin naisen seksuaalisuuteen liittyviä normatiivisia odotuksia, mutta mikään niistä ei tee sitä suoraan vaan negaation kautta. Tästä huolimatta yksineläjänaisista kertovilla stereotypioilla on kulttuurinen roolinsa normien mukaisen käyttäytymisen tukijana. Yksineläjästereotypioiden tehtävänä on kertoa siitä, millaista naiseuden ei tule olla ja kuinka naisten ei toivota yhteiskunnassamme käyttäytyvän.

Mielikuva heteroseksuaalisesta seksuaalista mielenkiintoa tuntevasta mutta halukkuutensa tarvittaessa hillitsemään kykenevästä naisesta edustaa kokoamassani 34 haastattelun aineistossa normatiivista, odotusten mukaista ja hyväksyttävää seksuaalisuutta. Diskurssi, jolla tämän mielikuvan rakentaminen aineistossani tapahtuu, on sisäisesti ristiriitainen mutta ristiriitaisuudessaankin elinvoimainen. Kaikki haastattelemani naiset rakentavat haastattelukysymyksiini vastatessaan huolellisesti käsitystä, jonka mukaan heidän oma seksuaalisuutensa kykenee täyttämään normiodotukset yksineläjänaisen asemasta huolimatta. Heidän tehtävänsä ei kuitenkaan ole helppo, koska normaaliksi mieltyvä naisen seksuaalisuus ja naisen asema miehensä puolisona liittyvät kulttuurissamme vahvasti yhteen. Yksineläjänaisen asema seksuaalisuuttaan toteuttavana naisena muodostuu kulttuuristen odotusten paineessa hyvin ris- 


\section{EPÄILYTTÄVÄ NAISHENKILÖ}

tiriitaiseksi: yhtäältä elämää vailla seksuaalista kanssakäymistä pidetään osoituksena epänormaaliudesta, mutta toisaalta vailla puolisoa olevan naisen seksuaalisuudenilmaukset tulkitaan stereotyyppisesti yhteisön moraalia uhkaavaksi tai muulla tavoin ei-hyväksyttäväksi seksuaalisuudeksi.

Puolisottoman ja lapsettoman yksineläjänaisen seksuaalisuuden epäillään poikkeavan muiden naisten seksuaalisuudesta. (13) Jo pelkkä yksineläjyys sinänsä riittää epäilysten syntymiseen. Jotta yksineläjänainen miellettäisiin seksuaalisuudeltaan normaaliksi ja hyväksyttävissä olevaksi naiseksi, hänen on kyettävä osoittamaan puolisottomiin ja lapsettomiin naisiin liittyvät stereotyyppiset mielikuvat omalla kohdallaan paikkansapitämättömiksi. Tähän tavoitteeseen päästäkseen yksineläjänaisen on puhuessaan tasapainoiltava onnistuneesti seksuaalisuutensa riittävän ilmaisemisen ja huonomaineiseksi naiseksi leimautumisen välillä. Yksineläjänaisen on saatava kuulijansa vakuuttuneeksi siitä, että hän tuntee halua seksuaaliseen kanssakäymiseen samalla tavoin kuin normaalien naisten odotetaan tuntevan. Toteennäyttämisen on kuitenkin tapahduttava sosiaalisesti hyväksyttävissä olevia keinoja käyttäen, jottei mielikuva seksuaalisuuttaan hillitsemään kykenevästä naisesta vaarannu. Lisäksi yksineläjänaisen tulee kyetä asettamaan sanansa siten, että hänen uskotaan kantavan vastuunsa myös itseään lähestyvien miesten seksuaalimoraalista. Odotusten mukaan yksineläjänaisen on huolehdittava siitä, etteivät miehet sorru moraalittomiin suhteisiin. Heteroseksuaalisille vailla seurustelukumppania oleville yksineläjänaisille lähtökohdat ovat kaikkein hankalimmat. Etenkin silloin, jos seurustelukumppania ei ole, yksineläjänaista saatetaan epäillä homoseksuaaliseksi, jollei hän pysty vakuuttamaan ympäristöään heteroseksuaalisuudestaan. Teot, joiden sisältö olisi riittävän vakuuttava, saattaisivat johtaa epäilyksiin heikosta seksuaalimoraalista. Esimerkiksi aktiivinen flirttailu läsnä olevien miesten kanssa voi tuottaa tulkinnan heteroseksuaalista halua tuntevasta naisesta. Samalla flirttailu saatetaan kuitenkin tulkita myös osoitukseksi yksineläjänaisen horjuvasta sukupuolimoraalista ja hänen heikosta kyvystään hillitä seksuaalista käyttäytymistään.

Useimmissa tutkimuksissa puolisoton nainen on nähty yksinhuoltajaäitinä ja lapseton nainen on mielletty miehensä puolisoksi. Tutkimuksia naisista, jota ovat sekä puolisottomia että lapsettomia, on tehty harvoin. Tutkimuksen puuttuminen ei kuitenkaan tarkoita sen tarpeettomuutta. Yksineläjänaisista kertova tutkimus nostaa esille yksineläjänaisten vaille huomiota jääneet kokemukset, mikä jo sinänsä on arvokasta. Lisäksi yksineläjyyttä tarkastelevalla tutkimuksella on laajemmalle ulottuva antinsa, sillä se avaa mielenkiintoisen näkökulman naisen sosiaalista ja kulttuurista asemaa käsittelevälle tutkimustyölle. Kun käyttäytyminen ja elämänkulku vastaavat yhteisön asettamia odotuksia, toiminnan taustalla vaikuttavien normien olemassaolo jää usein huomaamattomaksi. Noudattamatta jätettynä normiodotusten vaativuus sen sijaan väääämättä paljastuu. (Sulkunen 1992, 137.)

Normaaliksi mieltyvän naiseuden rakentuessa suurelta osin yhtäältä puolisosuhteen (Gittings 1985, 86; Gordon 1994, 1, 41; Niekka \& Petrelius 1993, 47, 58; Ojala \& Kontula 2002, 84-85; Reynolds \& Wetherell 2003, 489-490) ja toisaalta äitiyden kautta (Gittings 1985, 95-96; Gordon 1990, 47, 127; Gordon 1994, 1, 148; Ojala \& Kontula 2002, 86) puolisottomat ja lapsettomat yksineläjänaiset ovat kaksinkertaisen normirikkojan asemassa. Tutkimalla heidän kokemuksiaan ja tilannettaan 


\section{ARJA MäKinen}

on mahdollista vetää päivänvaloon myös niitä naissukupuoleen kohdistuva asenteita, odotuksia ja pelkoja, joiden olemassaolo, voimakkuus ja seuraukset jäävät helposti näkymättömiin vain normiodotusten mukaisesti käyttäytyneitä puolisoiksi ja äideiksi ryhtyneitä naisia tarkastelemalla.

\section{VIITTEET}

1. Artikkelini pohjautuu tekeillä olevaan väitöskirjaani. Yksineläjänaisen seksuaalisuus on yksi tulevan väitöskirjani teemoista. Muita väitöskirjani teemoja ovat yksineläjänainen työelämässä, mahdollisena puolisoehdokkaana ja potentiaalisena äitinä.

2. Useimmat haastattelemistani naisista näkivät haastattelupyyntöni kotipaikkakuntansa sanomalehdestä. Jotkut haastattelun antaneista olivat kuulleet osallistumismahdollisuudesta tuttaviltaan. Haastattelun keskimääräinen kesto oli hiukan vajaa tunti. Kaikki haastattelut on nauhoitettu kokonaisuudessaan. Aineiston laajuus on litteroituna noin 300 liuskaa. Artikkelissa esitetyt sitaatit ovat suoria lainauksia haastatteluaineistosta. Merkintä [..] tarkoittaa sitaatista poistamaani tekstiä. Poisjätetyt sanat joko toistavat jo mainitun asian hieman eri sanoilla, ovat asiayhteydestään irrallaan olevia sivuhuomautuksia tai kertovat haastateltavan tunnistamista helpottavista yksityiskohdista. Olen lisännyt hakasuluissa olevat sanat alkuperäiseen tekstiin, jotta teksti lyhennetyssä muodossaan säilyttäisi ymmärrettävyytensä. Alleviivaukset osoittavat ne sanat tai lauseen osat, joita haastateltava puheessaan erityisesti painottaa. Merkintä ... ilmaisee haastatellun jättävän lauseensa kesken. Kunkin sitaatin lopussa olevan numero kertoo, mistä haastattelusta sitaatti on lainattu. Varsinaisten viitteiden numeroista poiketen haastattelujen numerot on kirjoitettu kursiivilla.

3. Kuvausten yhteydessä olevat lähdeviitteet viittaavat teksteihin, jotka joko kommentoivat kuvauksessa esitettyjä väitteitä (ks. lähdeteos) tai olettavat yksineläjänaisten muistuttavan koostamaani kuvausta (vrt. lähdeteos).

4.-11. Johtopäätös perustuu / johtopäätökset perustuvat koko aineistooni (34 haastattelua).

12. Tuula Gordon (Gordon 1990, 1) on ehdottanut, että puolisottomista naisista käytettäisiin ilmaisua itsellinen nainen. Testasin sanan käyttöä kysymällä haastattelemieni naisten mielipiteitä. Muutamaa poikkeusta lukuun ottamatta sanaa kommentoineet naiset eivät halunneet tulla kutusutuiksi itsellisiksi. Sanan sanottiin synnyttävän mielikuvia itsekkyydestä ja välinpitämättömästä asenteesta muista ihmisiä kohtaan, kuulostavan liian koomiselta käytettäväksi asiatekstissä ja tuovan mieleen torpparit ja talonpojat assosioitumatta millään tavoin puolisottomiin ja lapsettomiin naisiin. Eija Maarit Ojala ja Osmo Kontula (2002) käyttävät tutkimuksessaan puolisottomista henkilöistä y/ksineläjä -sanaa. Tätä vaihtoehtoa kohtaamani yksineläjänaiset pitivät itsellistä parempana. Sanasta pidettiin, koska se ei sisällä puutumista ilmaisevaa ton- tai tön-liitettä (vrt. puolisoton, lapseton ja perheetön). Myös omissa korvissani yksineläjä mieltyy itsellistä neutraalimmaksi ilmaisuksi. Sanan alkuosa y ksin kertoo perheen jäsenten määrän ja loppuosa eläjä 


\section{EPÄILYTTÄVÄ NAISHENKILÖ}

muistuttaa siitä, etteivät yksineläjät ole "todellisen elämän" sivustaseuraajia vaan ihmisiä, jotka elävät omaa elämäänsä siihen sisältyvine iloineen, suruineen ja tärkeine tapahtumineen.

13. Yksineläjänaiset eivät suinkaan ole ainoa ihmisryhmä, jonka seksuaalisuuteen ja etenkin seksuaalimoraaliin kohdistuu runsaasti epäilyksiä. Valtaväestöstä tavalla tai toisella poikkeavista henkilöistä muodostetaan stereotyyppisiä mielikuvia ja heidän kykyään käyttäytyä normaaliksi mielletyllä ja moraalisesti hyväksyttävällä tavalla epäillään lähes säännönmukaisesti. Omasta viiteryhmästä poikkeaminen herättää epäilyksiä, vaikkakin eri vähemmistöryhmiin kohdistuvat epäilykset voivat poiketa sisällöltään toisistaan. (Ks. esim. Allport 1997; Nygård 1998). Vähemmistöryhmiin kohdistuvien epäilyksiin yleisellä tasolla liittyvät kysymykset ovat mielenkiintoisia, mutta niiden tarkasteluun ei ole mahdollista paneutua lyhyen artikkelitekstin yhteydessä.

\section{LÄHTEET}

\section{Tutkimusaineistot}

Litteroitu haastatteluaineisto. Haastateltuina 34 yksineläjänaista. Kaikkia haastatteluja on käytetty artikkelin lähdeaineistona. Haastattelut tehty vuonna 2004 Joensuussa, Jyväskylässä ja Tampereella. Haastattelija: Arja Mäkinen. Artikkelissa esitetyt suorat sitaatit on koottu seuraavista haastatteluista:

— Nro 5: nainen, s. 1969. Jyväskylä.

— Nro 7: nainen, s. 1963. Jyväskylä.

— Nro 9: nainen, s. 1963. Jyväskylä.

— Nro 11: nainen, s. 1960. Jyväskylä.

- Nro 17: nainen, s. 1961. Tampere.

- Nro 20: nainen, s. 1966. Tampere.

- Nro 24: nainen, s. 1962. Joensuu.

— Nro 26: nainen, s. 1970. Joensuu.

- Nro 28: nainen, s. 1965. Joensuu.

— Nro 29: nainen, s. 1962. Joensuu.

— Nro 29: nainen, s. 1963. Joensuu.

Koska syntymäaikatietoja ei ole käytettävissä, syntymävuosi on arvioitu vähentämällä haastatteluvuodesta (2004) haastateltavan ikä haastatteluhetkellä (x vuotta). Syntymävuosi pitää paikkansa alkuvuodesta syntyneiden osalta. Jos haastateltujen joukossa on loppuvuodesta syntyneitä, he ovat syntyneet ilmoittamaani ajankohtaa edeltävänä vuonna. 


\section{ARJA MäKInEN}

\section{Kirjallisuus}

AAPOLA, SINIKKA 1999: Murrosikä ja sukupuoli: julkiset ja yksityiset ikämäärittelyt. Suomalaisen Kirjallisuuden Seuran Toimituksia 763. Helsinki: Suomalaisen Kirjallisuuden Seura; Nuorisotutkimusseura.

ALLPORT, GORDON 1997: The Nature of Prejudice. Reading (Mass): AddisonWesley. [1955]

BEVAN, SAM \& BEVAN, KATE 1999: Interviews. Meaning in Groups. - Parker, Ian \& the Bolton Discourse Network (eds.), Critical Textwork. An Introduction to Varieties of Discourse and Analysis. Buckingham: Open University Press.

EDLEY, NIGEL 2001: Analysing Masculinity: Interpretative Repertoires, Ideological Dilemmas and Subject Positions. - Wetherell, Margaret \& Taylor, Stephanie \& Yates, Simeon (eds.), Discourse as Data: a Guide for Analysis. Milton Keynes: Open University.

ERIKSON, ERIK 1983: Identity: Youth and Crisis. London: Faber and Faber. [1968] GITTINGS, DIANA 1985: The Family in Question: Changing Households and Familiar Ideologies. Basingstoke: Macmillan.

GORDON, TUULA 1990: Feminist Mothers. Basingstoke: Macmillan.

— 1990: Johdanto. - Haatainen, Katri et al., Itselliset: vanhoja piikoja ja poikia vai meneviä sinkkuja? Helsingin yliopiston sosiologian laitoksen monisteita. Helsinki: Helsingin yliopisto.

- 1994: Single Women. On the Margins? London: Macmillan.

HAVINGHURST, ROBERT 1955: Human Development and Education. New York: Longmans, Green and Co. [1953]

JALLINOJA, RIITTA 1983: Suomalaisen naisasialiikkeen taistelukandet. Helsinki: WSOY.

JOKINEN, ARJA \& JUHILA, KIRSI 1999: Diskurssianalyyttisen tutkimuksen kartta. - Jokinen, Arja \& Juhila, Kirsi \& Suoninen, Eero (toim.), Diskurssianalyysi liikkkeessä. Tampere: Vastapaino.

JOKINEN, ARJA \& JUHILA, KIRSI \& SUONINEN, EERO 1993: Diskursiivinen maailma. - Jokinen, Arja \& Juhila, Kirsi \& Suoninen, Eero (toim.), Diskurssianalyysin aakkoset. Tampere: Vastapaino.

JOKINEN, EEVA 2005: Aikuisten arki. Helsinki: Gaudeamus.

JUHILA, KIRSI 1999: Kulttuurien jatkuvasti rakentuvat kehät. Tilanteisesta kulttuuriseen kontekstiin. - Jokinen, Arja \& Juhila, Kirsi \& Suoninen, Eero (toim.), Diskurssianalyysi liikkeessä. Tampere: Vastapaino.

JUVONEN, TUULA 2002: Varjoelämää ja julkisia salaisunksia. Tampere: Vastapaino.

LEHTONEN, JUKKA 2004: Näkymättömät nuorten mallit - seksuaalivähemmistöön kuuluvat opettajat. - Lehtonen, Jukka \& Mustola, Kati (toim.), "Eibän heterotkaan kerro...”. Seksuaalisunden ja sukupuolen rajankäyntiä työelämässä. Työministeriö. ESR tutkimukset ja selvitykset -sarja 2/04. Helsinki: Työministeriö.

LÖFSTRÖM, JAN 1999: Sukupuoliero agraarikulttuurissa: "Se vaan nyt on semmonen". Suomalaisen Kirjallisuuden Seuran Toimituksia 757. Helsinki: Suomalaisen Kirjallisuuden Seura. 


\section{EPÄILYTTÄVÄ NAISHENKILÖ}

MACDONALD, MYRA 1995: Representing Women: Myths of Femininity in the Popular Media. London: Edward Arnold.

MORING, ANNA 2003: Miksi lesbo ei meikkaa? - Tulva, feministinen aikakauslebti 2(2): 20-23.

NIEKKA, ILSE \& PETRELIUS, PÄIVI 1993: Suomalainen vanbapiikuus: tutkielma naisen naimattomunden kulttuurisesta määrittelystä. Jyväskylän yliopiston yhteiskuntapolitiikan laitos. Työpapereita 77. Jyväskylä: Jyväskylän yliopisto.

NYGÅRD, TOIVO 1998: Erilaisten historiaa: marginaalirybmät Suomessa 1800-luvulla ja 1900-luvun alussa. Jyväskylä: Atena.

OLLILA, ANNE: 1998: Jalo velvollisuus: virkanaisena 1800-luvun lopun Suomessa. Suomalaisen Kirjallisuuden Seuran Toimituksia 711. Helsinki: Suomalaisen Kirjallisuuden Seura.

OJALA, EIJA MAARIT \& KONTULA, OSMO 2002: Tarvitseeko minua kukaan? Keski-ikä̈setyksineläjätperhekeskeisessä yhteisössä. Väestöntutkimuslaitoksen julkaisusarja D40/2002. Helsinki: Väestöliitto.

POTTER, JONATHAN \& WETHERELL, MARGARET 2001: Unfolding Discourse Analysis. - Wetherell, Margaret \& Taylor, Stephanie \& Yates, Simeon (eds.), Discourse Theory and Practice: a Reader. London: Sage.

REYNOLDS, JILL \& WETHERELL, MARGARET 1993: The Discursive Climate of Singleness: The Consequences for Women's Negotiation of a Single Identity. - Feminism \& Psychology 13(4): 489-510.

RONKAINEN, SUVI 1994a: Sukupolvet ja seksuaalisuus. - Ronkainen, Suvi \& Pohjolainen, Pertti \& Ruth, Jan-Erik (toim.), Erotiikka ja elämänkulku. Helsinki: WSOY. -1994b: Seksuaalisuuden tyylit. - Ronkainen, Suvi \& Pohjolainen, Pertti \& Ruth, Jan-Erik (toim.), Erotiikka ja elämänkulku. Helsinki: WSOY.

RÄISÄNEN, ARJA-LIISA 1995: Onnellisen avioliiton ehdot: sukupuolijärjestelmän mиodostumisprosessi suomalaisessa avioliitto- ja seksuaalivalistusoppaissa 1865-1920. Helsinki: Suomen Historiallinen Seura.

SAARIKOSKI, HELENA 1998: Tytön maineen käsite ja huoraksi leimaamisen kansantapa. -Koskinen, Taava (toim.), Kurtisaaneista kunnian naisïn: näkökulmia Huoraakatemiasta. Helsinki: Yliopistopaino.

— (toim.) 2001: Mistä on buonot tytöt tehty? Helsinki: Tammi.

SANDFIELD, ANNA \& PERCY, CAROL 2003: Accounting for Single Status: Heterosexism and Ageism in Heterosexual Women's Talk about Marriage. - Feminism \& Psychology 13(4): 475-488.

STROKA, BARBARA 1985: Yksi on myös kokonaisluku. Vantaa: RV-kirjat. [1978]

SULKUNEN, PEKKA 1992: Johdatus sosiologiaan. Helsinki: WSOY. [1987]

SUONINEN, EERO 1999: Näkökulmia sosiaalisen todellisuuden rakentumiseen. - Jokinen, Arja \& Juhila, Kirsi \& Suoninen, Eero (toim.), Diskurssianalyysi liikkeeessä. Tampere: Vastapaino.

TOLVANEN, EERO 2001: Sinkku: elävänä elämässä. Helsinki: Karas-Sana.

UKKONEN, JENNI 1999: Tahdon, mutta... Sinkkunainen yksinäisyyden ja itsenäisyyden satimessa. - Paasonen, Susanna (toim.), Hääkirja: kirjoituksia rakkaudesta, romantiikasta ja sukupuolesta. Turku: Turun yliopisto. 


\section{ArJa Mäkinen}

VAKIMO, SINIKKA 2001: Paljon kokeva, vähän näkeyvä. Tutkimus vanhaa naista koskevista kulttuurisista käsityksistä ja vanhan naisen elämänkäytännöistä. Suomalaisen Kirjallisuuden Seuran Toimituksia 818. Helsinki: Suomalaisen Kirjallisuuden Seura.

WETHERELL, MARGARET 2001: Themes in Discourse Research: the Case of Diana. - Wetherell, Margaret \& Taylor, Stephanie \& Yates, Simeon (eds.), Discourse Theory and Practice: a Reader. London: Sage.

WILKINSON, HELENA 1996: Parbaassa seurassa: yksinäisyys - matka ja mahdollisuus. Hämeenlinna: Päivä. [1995]

YTM Arja Mäkinen on tohtori-opiskelija Tampereen yliopiston sosiaalipolitiikan ja sosiaalityön laitoksella. Hän työskentelee Invalidiliiton Jyväskylän kuntoutus- ja työklinikalla kuntoutussosiaalityöntekijänä. 